\title{
Foundations of Dental Technology: natomy and Physiology
}

Author(s)/Editor(s): Arnold Hohmann /

Werner Hielscher

Publisher: Quintessence Publishing Co Inc

Language: English

ISBN: 978-0-86715-612-6

Edition: $1 / \mathrm{e}$

Publish Year: 2014

Pages: 400, illustrated

Price: $\$ 98.00$

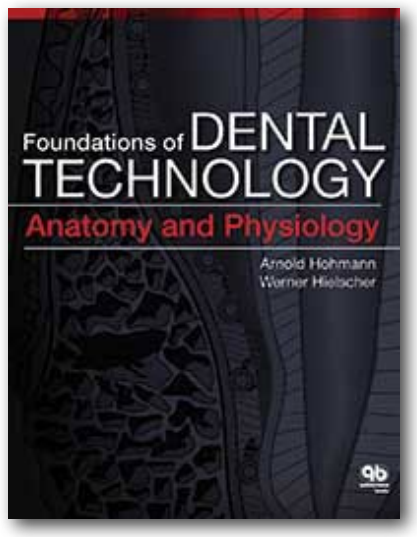

DOI: https://doi.org/10.25241/stomaeduj.2016.3(3-4).bookreview.6

The authors of "Foundations of Dental Technology: Anatomy and Physiology" have turned this book into an essential guide for dental technicians. The book focuses on the relationship between anatomical form and function in dental technologies. It has eleven chapters. The first chapter describes the fundamental concepts of dental technologies. The next two chapters discuss cells and tissues as independent functional units as well as the development and structure of dental tissues. Chapters four and five present and richly illustrate teeth and dentition morphology. The following chapter provides information about cranial anatomy. Chapters seven and eight cover the physiology of mandibular movement and how to transfer it into mechanical articulator devices. Chapter nine investigates the causes, physical changes and origin of diseases as well as their clinical appearance. The last two chapters speak about the methodology of orthodontic appliances and splint therapy. This book covers all necessary knowledge required by dental technicians to successfully complete their high-level technical work.

The Books Review is drafted in the reviewer's sole wording and illustrates his opinions.

Florin-Eugen

Constantinescu

DDS, PhD Student

ROPOSTURO - Holistic Dental

Medicine Institute

Bucharest, Romania

e-mail:

dr.florin.constantinescu@gmail.com 